\title{
Late Holocene paleoearthquake activity in the middle part of the Longitudinal Valley fault, eastern Taiwan
}

\author{
Wen-Shan Chen ${ }^{\mathrm{a}, *}$, I-Chin Yen ${ }^{\mathrm{a}}$, Keegan P. Fengler ${ }^{\mathrm{b}}$, Charles M. Rubin ${ }^{\mathrm{b}}$, \\ Chi-Cheng Yang ${ }^{a}$, Hsiao-Chin Yang ${ }^{a}$, Hui-Cheng Chang ${ }^{c}$, Chii-Wen Lin ${ }^{c}$, \\ Wei-Hsiung Lin ${ }^{c}$, Yen-Chiu Liu ${ }^{c}$, Yen-Hui Lin ${ }^{c}$ \\ ${ }^{a}$ Department of Geosciences, National Taiwan University, Taiwan ROC \\ ${ }^{\mathrm{b}}$ Department of Geology, Central Washington University, Ellensburg, USA \\ ${ }^{\mathrm{c}}$ Central Geological Survey, Taiwan ROC
}

Received 7 February 2007; received in revised form 11 September 2007; accepted 29 September 2007

Available online 12 October 2007

Editor: R.D. van der Hilst

\begin{abstract}
The Longitudinal Valley fault in eastern Taiwan is the most important arc-continent collisional boundary fault between the Philippine Sea plate and the Eurasian continent. The 50\% amount of collisional deformation partitioned on the fault has considered implications for seismic hazard. Our paleoseismological work on the middle segment (the Juisui fault) of the Longitudinal Valley fault has shown that the fault occurred intensive seismicity of four paleoearthquakes of $1951 \mathrm{AD}, \mathrm{P} 2$ event $<260 \mathrm{cal} \mathrm{yr} \mathrm{BP}, 150<\mathrm{P} 3$ event $<290-440$ cal yr BP, and $500<$ P4 event $<640$ cal yr BP during the past 700 yr. It indicates a relatively short recurrence interval of about 170-210 yr. In addition to analysis the behavior of the Juisui fault using GPS and paleoseismic data, they suggest that the decreasing GPS velocities on the hanging wall reflect strain accumulation as a result of the locking at a shallow depth, and the great earthquake often produced a visible surficial rupture of more than 0.65 -m-high vertical displacements. It is clearly different from the southern segment of the Chihshang fault which creeping is prevalent during interseismic periods.
\end{abstract}

Published by Elsevier B.V.

Keywords: Taiwan orogenic belt; Longitudinal Valley fault; paleoseismology; slip rate; recurrence interval

\section{Introduction}

The Longitudinal Valley fault passes through the eastern Taiwan, where it is the most obvious surface expression of the junction of the Philippine Sea plate and the Eurasian continent. Three most recent great earthquakes on the boundary fault ruptured its northern and middle

\footnotetext{
* Corresponding author.

E-mail address: wenshan@ntu.edu.tw (W.-S. Chen).
}

sections in 22/10/1951, 25/11/1951, and 10/12/2003, respectively. The 1951 Hualian $(\mathrm{Ms}=7.4,22 / 10 / 1951)$ and Taitung earthquakes $(\mathrm{Ms}=7.1,25 / 11 / 1951)$ caused the rupture of the north and middle segments of the Longitudinal Valley fault, respectively (Fig. 1a and b) (Hsu, 1956). However, the boundary fault is very seismically active, with about $30 \%$ of earthquakes per year in Taiwan being due to this boundary. Studies have been carried out to relocate these earthquakes to find focal mechanism solutions to a cluster of small earthquake and 
the larger earthquakes by studying the seismotectonic framework of the plate boundary (Cheng et al., 2002; Wu et al., 2006).

The Longitudinal Valley fault can be subdivided into four segments according to its structural, stratigraphic, and seismic characteristics, namely, the Linding, Juisui, Chihshang, and Lichi faults (Fig. 1b). Interseismic creeping seems to be very common in all of the segments except for the Juisui fault which has been aseismic in $M_{\mathrm{L}}>3$ events. The other three have displayed a higher level of seismicity of $M_{\mathrm{L}}$ 5-6.8 during large earthquakes for several decenniums (Kuochen et al., 2004). For this reason, we suspect that the great coseismic deformation probably occurred along the Juisui fault.

The Longitudinal Valley fault in eastern Taiwan is a mature arc-continent collisional boundary fault during the past 6-5 million yr (Liu et al., 2000, 2001) that accommodated a significant shortening between both plates. Many studies attempted to understand how the deformation is partitioned between the numerous active faults in the Taiwan orogenic belt (Simoes and Avouac, 2006; Simoes et al., 2007). In the 1999 Chi-chi earthquake, the Chelungpu fault ruptured to give a horizontal slip rate of $5.6 \mathrm{~mm} / \mathrm{yr}$, which has resulted in a $7 \%$ of the total horizontal shortening of the Taiwan orogenic belt. The fault has a short recurrence interval of between 200 and $700 \mathrm{yr}$ (Chen et al., 2004, 2007, in press). Global positioning system (GPS) data in eastern Taiwan have proved that the Coastal Range (the Philippine Sea plate) is converging towards the Central Range (the Eurasian continent) at a velocity of $35-40 \mathrm{~mm} / \mathrm{yr}$, which indicates that the boundary fault is responsible for about $50 \%$ accommodation of the northwest shortening over the past decade (Yu and Liu, 1989; Yu and Kuo, 2001). We suspect that from the great shortening rate those earthquakes along the Longitudinal Valley fault may recur at short intervals. However, because there are few reliable data for the most recent events in the Longitudinal Valley fault in terms of recurrence interval and slip rate, we propose to examine the behavior of the current aseismic segment of the Juisui fault that is a part of the larger Longitudinal Valley fault to determine whether this is in fact the case.

Much evidence of active tectonics has been reported at the Longitudinal Valley fault, most of which is based on Holocene geomorphological and geodetic indications (Yu and Kuo, 2001; Chen, 1974; Chen et al., 1991; Shyu et al., 2006; Yu and Lee, 1986; Yu et al., 1992). We present the results of the first paleoseismological exploration of the Juisui fault and identify the coseismic surface faulting that has been produced by paleoearthquakes, which is important to delineate the timing, recurrence intervals, and slip rate of the fault.

\section{Regional neotectonic setting}

The plate boundary fault in the Longitudinal Valley is a collision suture that separates the two tectonic domains of the Central and Coastal Ranges (Fig. 1a). The Central Range which is the western domain, consists of Tertiary slate and Mesozoic-Paleozoic green-schist, marble and gneiss, and is an ongoing orogenic belt that was originally thrown up by an arc-continent collision during 6-5 Ma ago (Liu et al., 2000, 2001; Suppe, 1981). In contrast, the Coastal Range, which is the eastern domain, consists of Miocene volcanics, Plio-Pleistocene deep-sea deposits, and mélange (Fig. 1a) (Chen, 1988, 1997a,b; Chen and Wang, 1988; Teng, 1987). During the late Pleistocene, continuous collision resulted in the complete welding of the Coastal Range to the Central Range along the Longitudinal Valley fault. Currently, the fault is characterized by an active fault that displaces late Cenozoic volcanics and deep-sea deposits over older metamorphic rocks. The upthrown domain of the Coastal Range is marked by fairly continuous scarps of alluvium, fluvium and prominent bedrock that form a series of Holocene terraces along the Longitudinal Valley fault.

The plate boundary between both the two ranges has developed a broad shearing zone of the Lichi mélange during the collision process, and from pervasive shearing features within the mélange, we can surmise that the boundary fault displayed a left-lateral strike-slip motion during the Plio-Pleistocene era (Barrier and Angelier, 1986; Chen, 1997a,b). Mélange exposures and field observations of intersecting foliations in the Longitudinal Valley fault zone, however, show that the eastdipping foliation of the reverse shearing cuts across the foliation of the strike-slip shearing (Lin, 1993). These data are important in the development of a motion history of the Longitudinal Valley fault, as they imply that late Pleistocene-Holocene faulting changed the strike-slip somewhat to the reverse motion, which is consistent with GPS observations.

\section{Segmentation of the Longitudinal Valley fault}

The Longitudinal Valley fault trace is exposed on land for about $150 \mathrm{~km}$, and its geomorphology can clearly be seen as consisting of Holocene terrace offset and warping, sag ponds, and pressure ridges (Shyu et al., 2006; Hsu, 1962; York, 1976; Bonilla, 1977). Based on its stratigraphy, geomorphology, and active tectonic behavior, the fault can be subdivided into four segments, namely, the Linding, Juisui, Chihshang, and Lichi faults (Fig. 1a and b). The rupture boundaries of the segments are unclearly defined, because most of the 


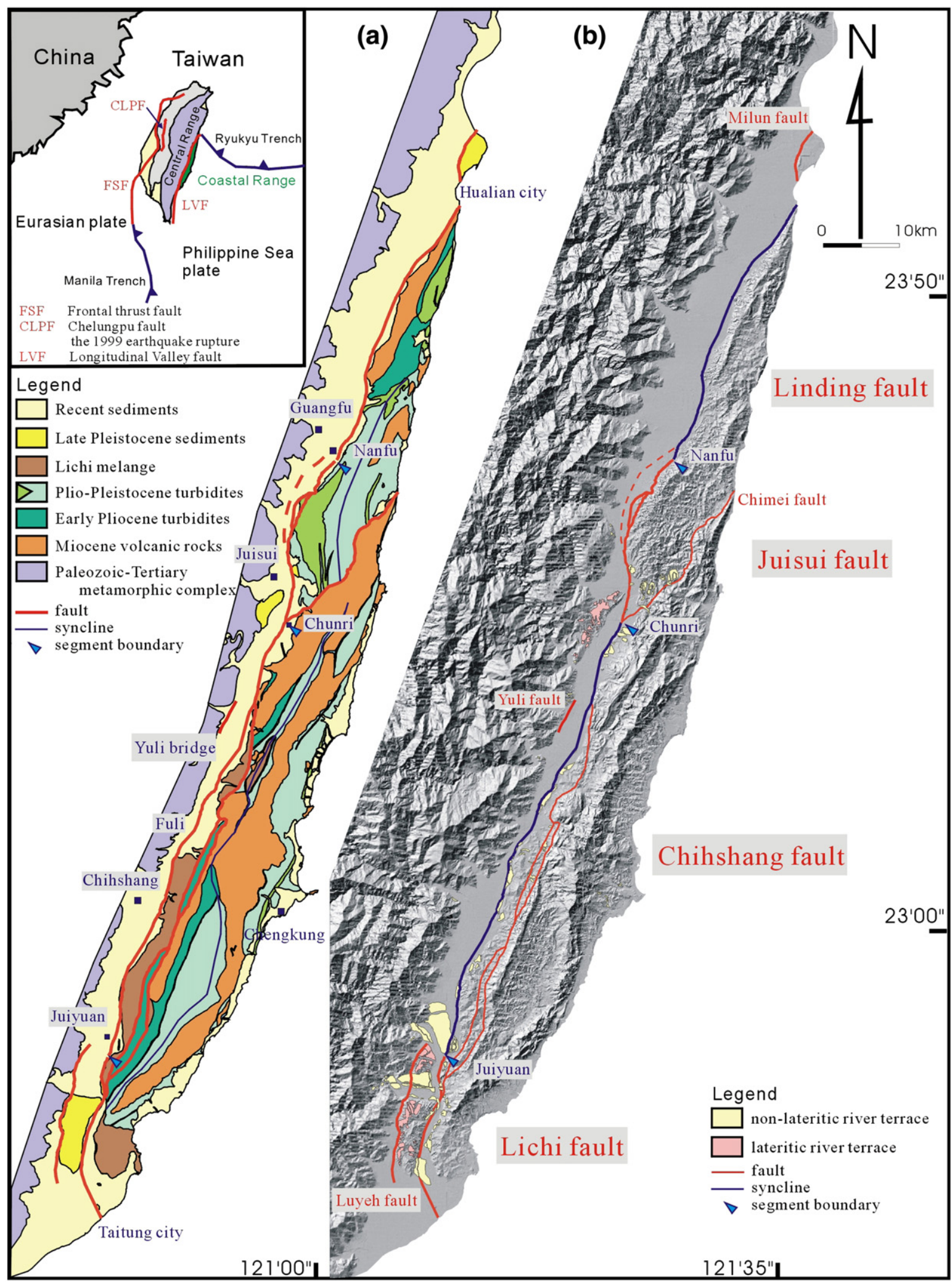


Longitudinal Valley fault trace lies along the Hualian, Hsiukuluan, and Peinandachi rivers, and is thus hidden beneath recent fluvial deposits. In this study, we use the structural discontinuities of historical earthquake ruptures, geodetic observations, and topographic expression to locate the fault boundary and define the four segments.

\subsection{Linding fault}

Data from the distribution of relocated earthquakes in the period 1991 to 2002 shows that the Linding fault trends $\mathrm{N} 20^{\circ} \mathrm{E} / 50^{\circ} \mathrm{E}$ (Kuochen et al., 2004). The fault is located at the northernmost segment of the Longitudinal Valley fault, which stretches $32 \mathrm{~km}$ south from Hualian river mouth to Nanfu (Fig. 1a and b). Geodetic observations also reveal a left-lateral strikeslip fault with a reverse motion component ( $\mathrm{Yu}$ and Liu, 1989; Yu and Kuo, 2001; Chen, 1974; Chen et al., 1991). The relative displacement trends on both sides of the Linding fault indicate that the Coastal Range moves at a velocity of $30 \mathrm{~mm} / \mathrm{yr}$, with an azimuth at $16-23^{\circ}$ relative to the Central Range (Yu and Liu, 1989). Most of the fault trace lies along the Hualian river, therefore, the landscapes cannot be delineated active tectonic geomorphology.

\subsection{Juisui fault}

The Juisui fault, which stretches $33 \mathrm{~km}$ south from Nanfu to Chunri, was ruptured during the 1951 Ms 7.1 Taitung earthquake (the first shock) (Fig. 1a and b). The rupture shows a left-lateral reverse fault, which is consistent with the fault plane solution of reverse faulting (Hsu, 1962; Cheng et al., 1996). The background seismic data for the 1991 to 2002 period shows the hypocenter distribution to be more complicated in this area, with an indistinctly seismic zone of $40-50^{\circ} \mathrm{E}$ dipping down to $20 \mathrm{~km}$ in depth (Kuochen et al., 2004). Geological mapping also shows the fault occurred on an east-dipping plane, which caused Pleistocene deep-sea turbidites to be thrown up the late Pleistocene fluvial deposits (Wang and Chen, 1993). The fault is well expressed geomorphically, and is characterized by fault scarp, warped terrace, and northeast-trending pressure ridges along much of its mapped length. In addition,
GPS observations also show the Coastal Range to have been thrust over the Central Range along the fault at an azimuth of $284-294^{\circ}$. The behavior of the Juisui fault differs from that of the southern segment of the Longitudinal Valley fault of the Chihshang fault, the shallow surface of the Chihshang fault is rapidly creeping. The 1951 earthquake rupture shows the fault to end where it intersects with the Chimei fault (Fig. 1a and $b$ ).

\subsection{Chihshang fault}

The Chihshang fault, which stretches for $65 \mathrm{~km}$ from Chunri to Juiyuan, is also characterized by the clear displacement and warping of Holocene river terraces on the hanging wall (Fig. 1b). Geological mapping shows the Plio-Pleistocene Lichi mélange to have been thrust over the late Pleistocene-Holocene fluvial deposits along the fault (Wang and Chen, 1993; Chen, 1997a,b; Lin, 1993; Hsu, 1962). During the 1951 Ms 6.8 Taitung earthquake (second shock), the fault seemingly did not cause a conspicuous surface rupture. Photographs show surface cracks that may have been caused by gravitational slump and liquefaction-induced sinking (Hsu, 1962), but we cannot completely rule out the generation of a surface deformation of some tens centimeters along the fault trace.

Currently, the Chihshang fault is continuously creeping at the ground surface, and deforms buildings, bridges, and cracks pavements. The creeping in the Yuli Bridge, Fuli, Chihshang, and Juiyuan areas is proceeding at a rapid rate of about $15-20 \mathrm{~mm} / \mathrm{yr}$ (Yu and Kuo, 2001; Lee et al., 2003). This creeping behavior allows us to define the northern and southern boundaries of the fault at the Churi and Juiyuan, respectively (Fig. 1b). The December 10, 2003 Mw 6.8 Chengkung earthquake is associated with ground deformation in the area from Churi to Juiyuan with the largest coseismic displacement near the fault trace being about $13 \mathrm{~cm}$ shortening and $26 \mathrm{~cm}$ uplifting (Wu et al., 2006; $\mathrm{Hu}$ et al., 2007). The distribution of the series of earthquakes that comprised the $2003 \mathrm{Mw} 6.8$ Chengkung earthquake and the relocated 1991-2002 earthquakes intimates a well-defined fault geometry that dips eastward down to a $10-\mathrm{km}$ depth at $60^{\circ}$, and down to a $30-\mathrm{km}$ depth at $45^{\circ}$ (Wu et al., 2006; Kuochen et al.,

Fig. 1. (1a) Geologic map of the Coastal Range. Box in Fig. 1a is the study area. (2b) Background is shaded DEM for $40 \mathrm{~m}$ pixel. Fault map in the Coastal Range is modified from Wang and Chen (1993). The Longitudinal Valley fault is subdivided into four segments of the Linding, Juisui, Chihshang, and Lichi faults. Blue triangles express the border of fault segment. A-A' (Fig. 8) and B-B' (Fig. 9) lines show geologic profiles across the Juisui and Chihshang faults. Horizontal velocities of GPS data projected are onto profiles. 
2004; Hu et al., 2007). The fault plane solution for large earthquakes came up with a reverse fault with a leftlateral strike-slip component (Wu et al., 2006; Cheng et al., 1996; Hu et al., 2007; Shin and Chang, 1992). Moreover, geodetic observations of the relative horizontal displacement on both sides of the fault reveal that at an azimuth of $284^{\circ}$ relative to the Central Range, the Coastal Range exhibits a steady surface creep of 23 $23.8 \mathrm{~mm} / \mathrm{yr}$ in the Yuli area, 26.4-28 mm/yr in the Chihshang area, and $26-26.8 \mathrm{~mm} / \mathrm{yr}$ in the Juiyuan area (Yu and Kuo, 2001).

\subsection{Lichi fault}

The Lichi fault, which stretches for $20 \mathrm{~km}$ from Juiyuan to Taitung city, is also characterized by the clear displacement and warping of the late Pleistocene strata, which are overlain by the Lichi mélange. The mélange represents a collision complex that is exposed on land to form a wide shear zone of about $2-8 \mathrm{~km}$ in width in the southern portion of the Coastal Range (Chen, 1997a,b). The westernmost boundary of the Lichi mélange is just identified as the Lichi fault (Fig. 1a) (Hsu, 1956; Wang and Chen, 1993).

Geodetic observations of the relative movement at an azimuth of $312^{\circ}$ relative to the Central Range reveal the Coastal Range to exhibit horizontal shortening at a rate of $26 \pm 0.8 \mathrm{~mm} / \mathrm{yr}$ across the Luyeh and Lichi faults as a result the two reverse faults. Evidence from GPS data across the Luyeh and Lichi faults reveals horizontal shortening to be occurring at a rate of $13.8 \pm 1.2 \mathrm{~mm} / \mathrm{yr}$ and $12 \pm 1.8 \mathrm{~mm} / \mathrm{yr}$, respectively. It appears that the slip rate of the Lichi fault, which is the southernmost fault segment, is quite different from the slip rates of the Juisui and Chihshang faults.

\section{Paleoseismological studies}

We focus on the Juisui fault, which produced at least a $25-\mathrm{km}$ long visible surface rupture during the 1951 Taitung earthquake. The original mapping of the 1951 earthquake rupture was very simple and incomplete (Hsu, 1956), because much of it is located along the Hsiukuluan River and the fault trace has been covered by alluvial deposits or destroyed by farmland development. We therefore reinvestigated the rupture, and interviewed people who experienced the 1951 earthquake to help us to select the trenched sites and map the ground rupture in detail. In the course of our investigations, we also found a branched fault that was caused by the 1951 earthquake that was not included on previous maps (Fig. 2a).
We excavated three trenched sites across the Juisui fault to determine the large earthquake recurrence. These trenched sites were located near the northern tip of the 1951 earthquake rupture on the west face of the Coastal Range (Fig. 2a). The mountain face in the study area has developed several alluvial fans that are characterized by a predominance of quartizitic pebbles and cobbles that derive from the Pleistocene conglomerate of the Coastal Range. Several phases of Holocene folded alluvialterraces on the Coastal Range appear to reflect tectonic activity that is due to an active fault. In this area, the Juisui fault has branched into two parallel strands $900 \mathrm{~m}$ apart as a result of surface ruptures during the 1951 earthquake (Fig. 2a). The western strand is bounded by the Longitudinal Valley and Coastal Range along the frontal hills, and the eastern strand is located within the Coastal Range and has displaced the alluvial fans. As previous studies found only the eastern strand, they suggested a northeasttrending reverse fault (Hsu, 1956). We combine the trenching observations across the two strands disrupted strata data, discordant angular relations, and ${ }^{14} \mathrm{C}$ dating results to examine the fault behavior in much more detail.

\subsection{Anding Bridge site}

The eastern strand of the 1951 earthquake rupture crosses an alluvial fan to the north of Anding Bridge. Some topography in the form of a 3-0.5-m high and 900$\mathrm{m}$ long visible scarp has been preserved (Fig. 2b), but most of the scarp has been destroyed by streams and farmland development. Two trenches (ADB-1 and ADB-2) $23 \mathrm{~m}$ long, $10 \mathrm{~m}$ wide, and $6 \mathrm{~m}$ deep were made across the scarp on the Anding Bridge site in as approximately east-west direction. The trenches clearly expose three depositional successions (Fig. 3a), each of which consists of stratified gravels (Gs) and matrixsupported gravels $(\mathrm{Gm})$ of debris- and stream-flow sediments (Fig. 4) that are capped by an organic-rich sand/ soil layer $(\mathrm{O})$ that has been slightly modified by pedogenic processes. The gravel beds have an eroded and sharp lower contact which implies that they were formed by the rapid and high-energy deposition of alluvial channels during storm periods. The high organic content and pedogenic origin of these alluvial deposits suggest that they resulted from the settling of flood sediments and a long period of non-deposition and plant growth that favored the organic enrichment process. We identified eleven depositional units on the basis of their distinctive lithologies. These deposits cannot be detected in a typical colluvial wedge, probably because of storm erosion, such as the erosion of the 1951 earthquake scarp by the unit Gs0 gravel bed in trench ADB-2 (Fig. 3b). 

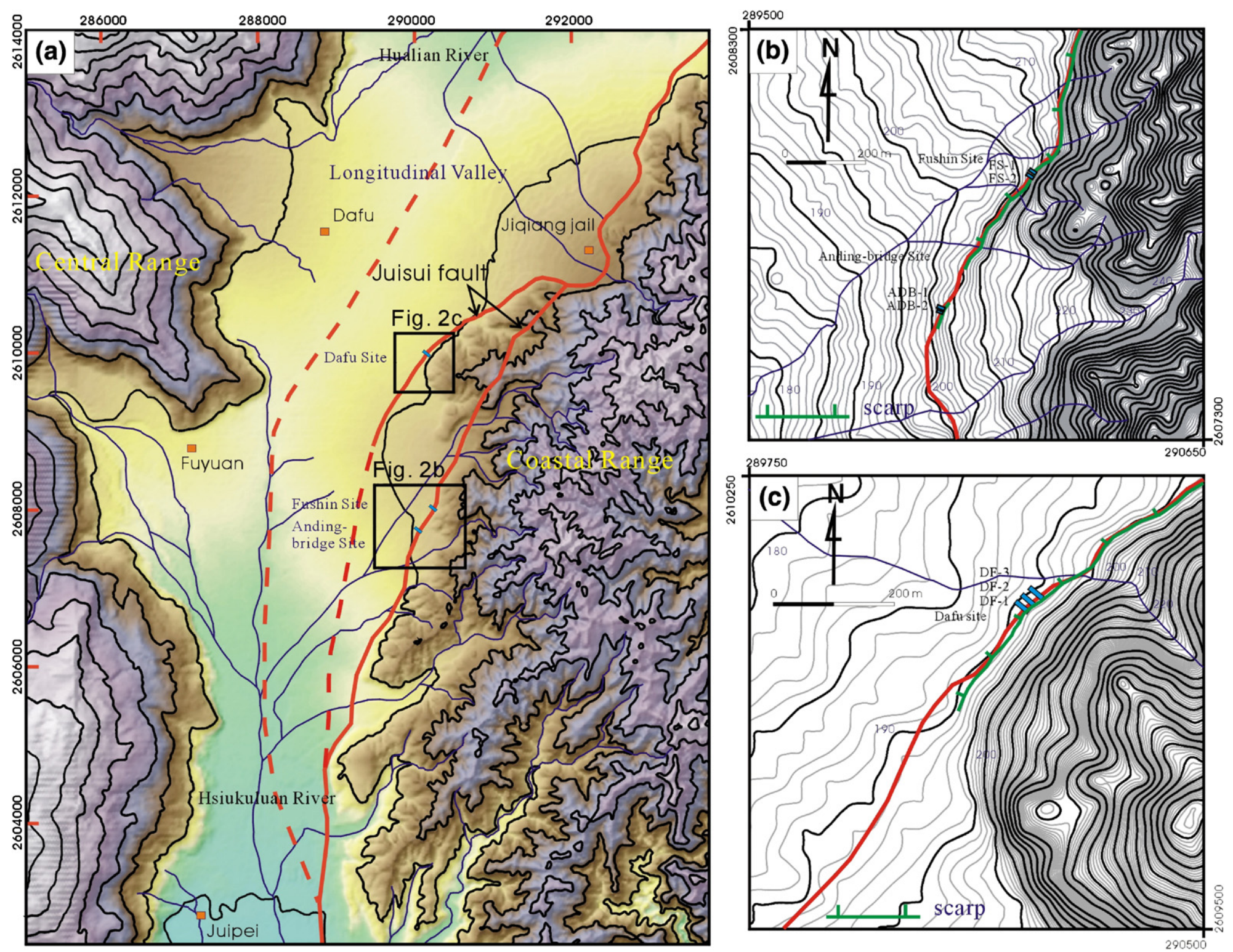

Fig. 2. (2a) Fault map in the study area, red lines were confirmed as the position of the 1951 earthquake ruptures, and dash lines are inferred fault trace. (2b) Location map of the Anding Bridge and Fushin sites that are excavated across the eastern fault strand of the 1951 earthquake rupture. The geomorphic expression shows that the Anding Bridge site is located at an alluvial fan. (2c) Location map of the Dafu site that is excavated across the western fault strand of the 1951 earthquake rupture. The geomorphic expression shows that the Dafu site is located at the western frontal Coastal Range. 


\section{West}

\section{East}

\section{(a) TrenchADB-1}

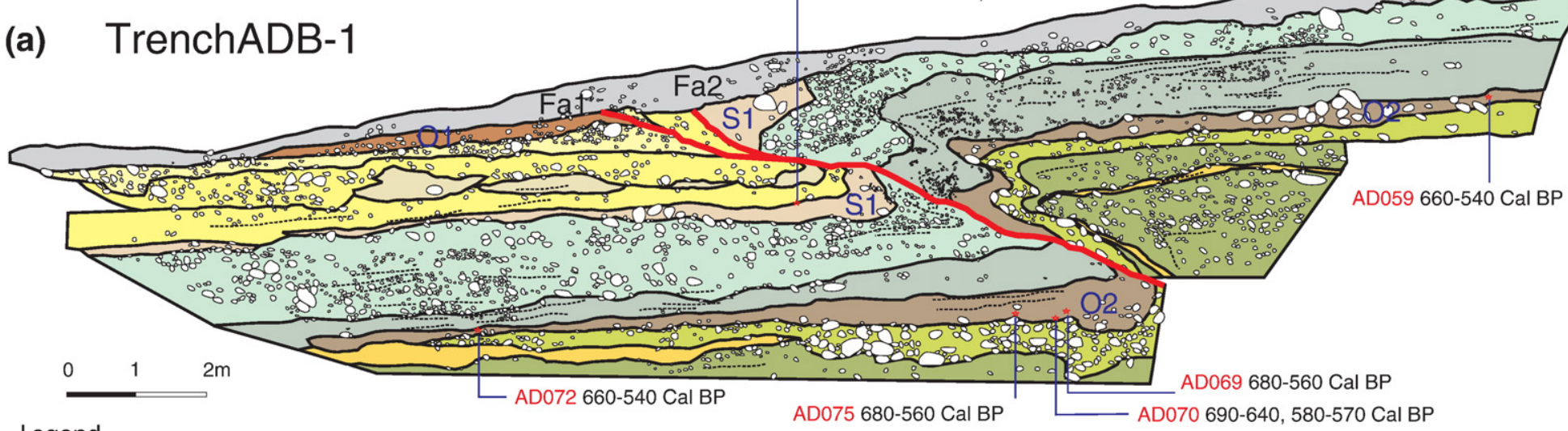

Legend

$\square$ Mold-human modified

$\square$ Gs0 stratified gravel < 50 BP yr
O1 soil < 300 Cal BP
Gm1 gravel (matrix-supported)
Gs1 stratified gravel
S1 sand 300-530 Cal BP
Gm2 gravel (matrix-supported)
Gs2 stratified gravel
O2 soil 540-690 Cal BP
Gm3 gravel (matrix-supported)
Gs3 stratified gravel
Faults

\section{(b) TrenchADB-2}

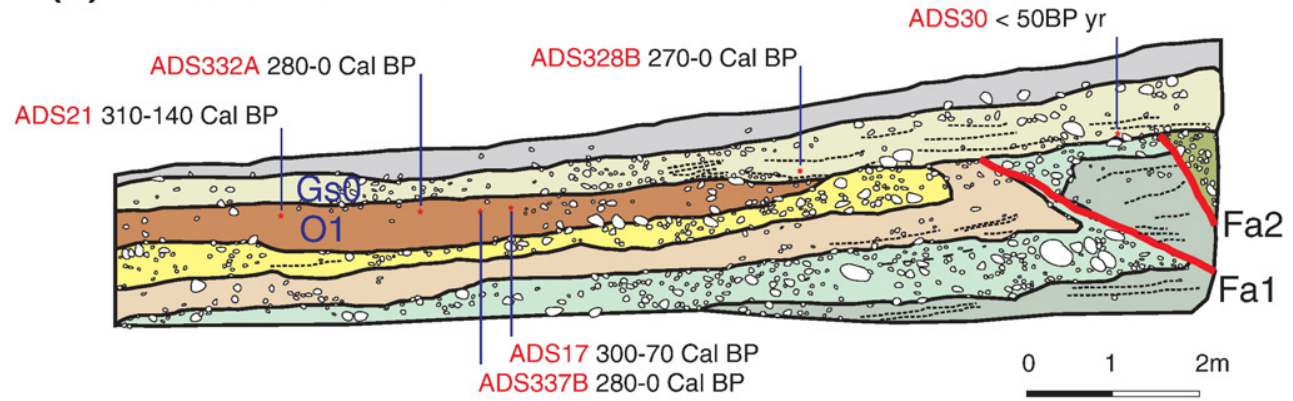

Fig. 3. Trench logs and dated stratigraphy of trench ADB-1 (3a) and ADB-2 (3b). Ten units of gravel and sandy deposits, the 1951 rupture (fault Fa1), and a paleoearthquake thrust of fault Fa2 are observed in trench ADB-1. The $\mathrm{O} 2$ soil layer has 2.5-m vertical displacement across the thrust fault. In trench ADB-2, Gm2 gravel bed has 0.75 -m vertical displacement across fault Fa1 of the 1951 earthquake rupture. 


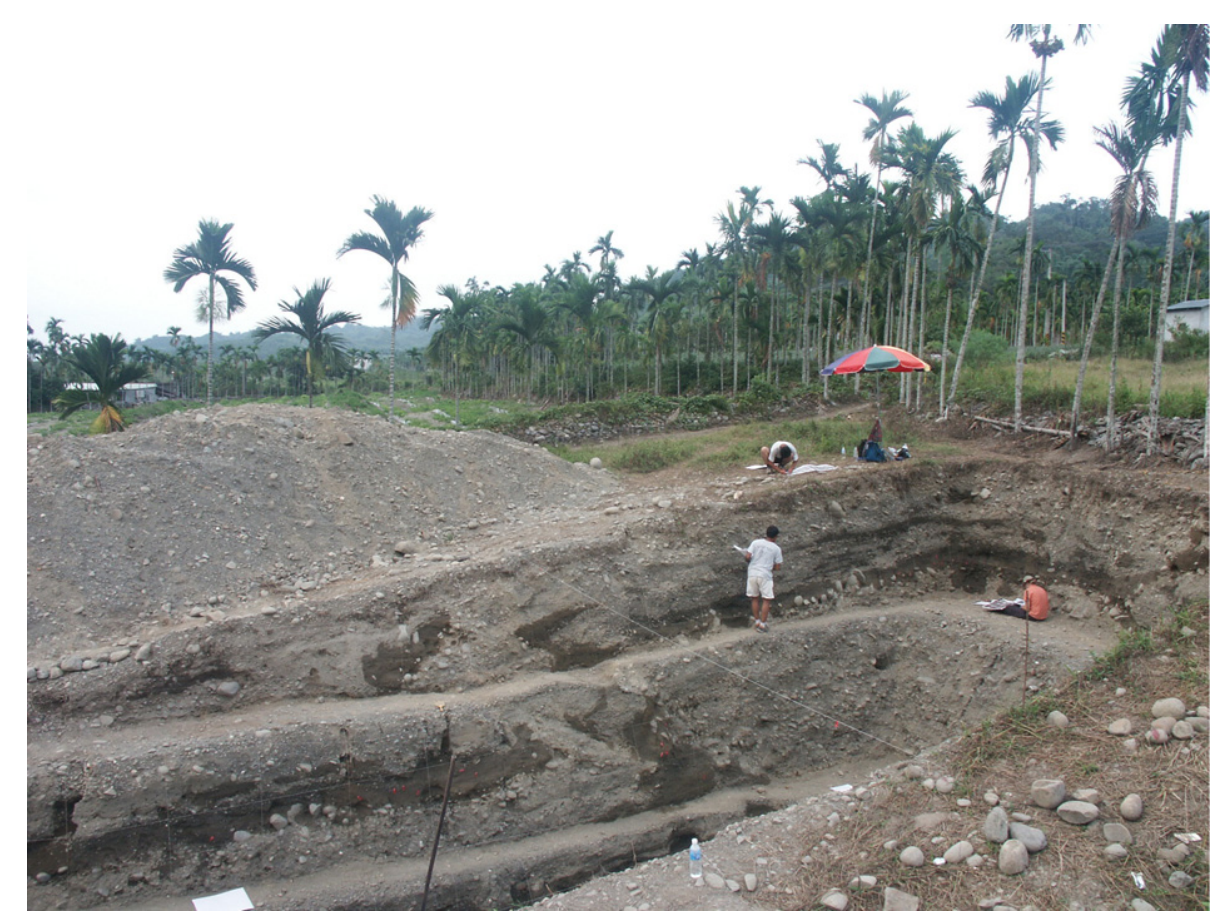

Fig. 4. Photograph showing northern wall of the ADB-1 trench (Fig. 3a). The fault strand cuts through gravel and sand beds.

In trench ADB-1, the deformation is expressed as an asymmetric fold with a hanging wall anticline and a footwall syncline (Fig. 4). The total vertical displacement of unit $\mathrm{O} 2$ across the fault $\mathrm{Fa} 2$ is $2.5 \mathrm{~m}$. The fault plane follows the orientations $\mathrm{N} 12^{\circ} \mathrm{E} / 26^{\circ} \mathrm{E}$, where it branches into two ruptures (Fa1 and Fa2) near the surface (Fig. 3a). The analysis of the two trenches reveals two displacement events along the two faults. Fault Fal was responsible for the displacement of the top sequence of units $\mathrm{O} 1, \mathrm{Gm} 1$, and Gs1, and was apparently sealed by unit Gs0 of the recent deposits in trench $\mathrm{ADB}-2$, the ${ }^{14} \mathrm{C}$ dating of which reveals its age to be $<50 \mathrm{yr}$ (AD030). The vertical displacement of the most recent event (E1), which was responsible for the top of units Gs2 across fault Fa1, is $0.75 \mathrm{~m}$ in trench ADB-2 (Fig. 3b). The displacement in trench ADB-1 cannot be estimated because the top sequence has been modified by agricultural activity. The results from the ${ }^{14} \mathrm{C}$ dating of unit $\mathrm{O} 1$ suggest an age of 140-300 cal yr BP (AD017, AD21). The Ea1 event therefore occurred after 140-300 cal yr BP (Fig. 5a). The landowner stated that an upward warping of the ground surface of about two feet occurred during the 1951 earthquake, and we therefore suggest that the Eal event occurred during the 1951 earthquake. The occurrence of the $\mathrm{Ea} 2$ event is indicated by the fact that fault $\mathrm{Fa} 2$ cuts the depositional sequence from unit Gs3 to $\mathrm{Gm} 1$ and is covered by unit $\mathrm{M}$ on the upper surface, which has been modified by agricultural activity. A detrital charcoal sample was collected for ${ }^{14} \mathrm{C}$ dating from unit $\mathrm{O} 2$, and an intersection age of 330-500 cal yr BP (AD056) was determined. Five samples that were collected from unit O3 yielded an intersection age of 570-660 cal yr BP (AD059, 069, 070, 072, 075). In terms of the chronology of the displacement, the Ea2 event occurred between 140 cal yr BP and 330-500 cal yr BP (Fig. 5a). The restoration of the displacement was caused by fault $\mathrm{Fa} 1$, and therefore the remnant of the vertical displacement is estimated to be $1.75 \mathrm{~m}$ high and was caused by the Fa2 faulting.

\subsection{Fushin site}

The Fushin site is located about $400 \mathrm{~m}$ north of the Anding Bridge site. The selection of this trench site was determined by historical records and certain geomorphological criteria. Two 23-m long, 10-m wide, and 6-m deep trenches (FS-1 and FS-2) were excavated in an approximately east-west trending across a gentle west-facing slope on the eastern strand along the frontal hills (Fig. 2a and $b$ ). The stratigraphic succession in the two trenches is composed mainly of organic-rich soils, alluvial and colluvial gravels, which we divided into 12 units to enable us to map and correlate the trench exposures (Fig. 6a and b). The lower unit Gc8 consists of matrix-supported gravels that were formed by debris flow from nearby hillsides. On top of unit Gc8 lies an unconformably deposit of organic- 


\section{(a) Anding-bridge site}

Ea1 event=1951AD $(0.75 \mathrm{~m})$



(b) Fushin site

Eb1 event=1951AD (1.2m)

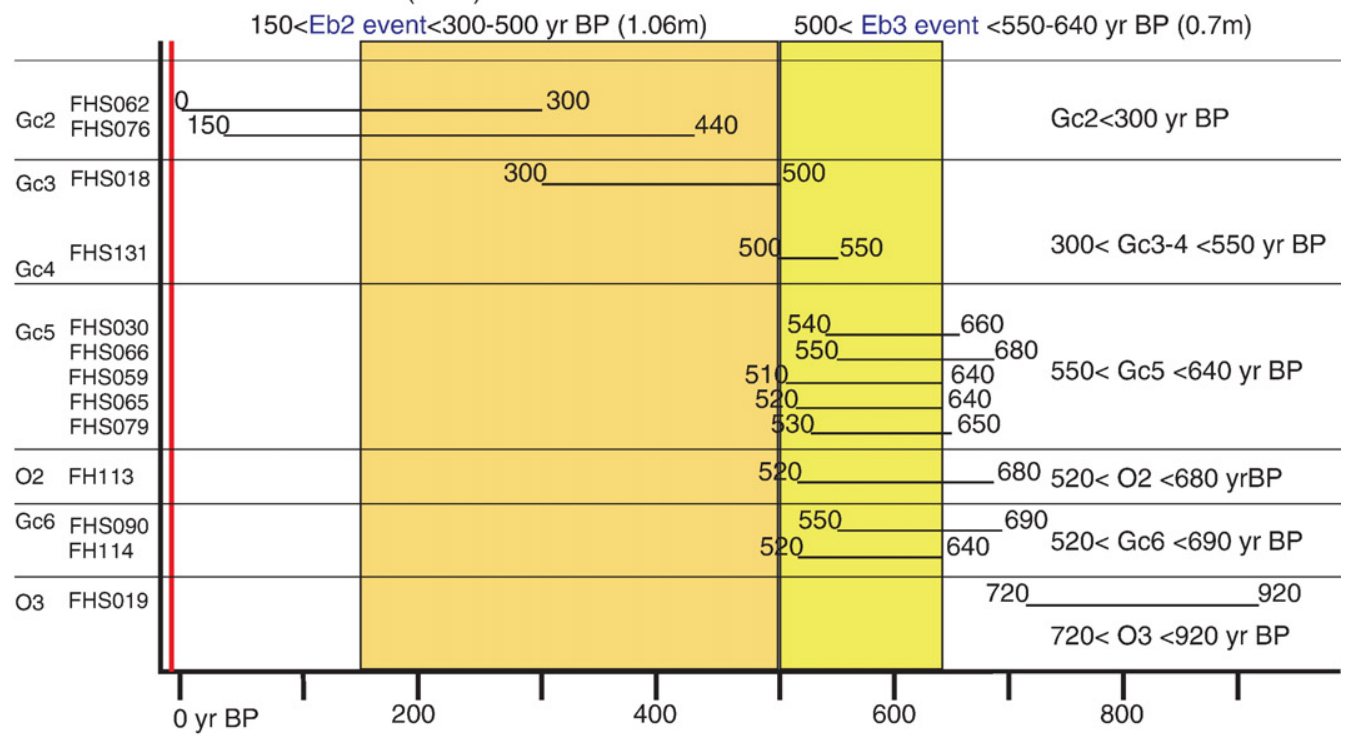

(c) Dafu site

$$
\begin{aligned}
& \text { Ec1 event=1951AD }(1.0 \mathrm{~m}) \\
& \text { Ec2 event }<260 \text { yr BP }(1.22 \mathrm{~m})
\end{aligned}
$$

$150<$ Ec3 (Ec4) event<290-440 yr BP $(2.75+0.65=3.4 \mathrm{~m})$

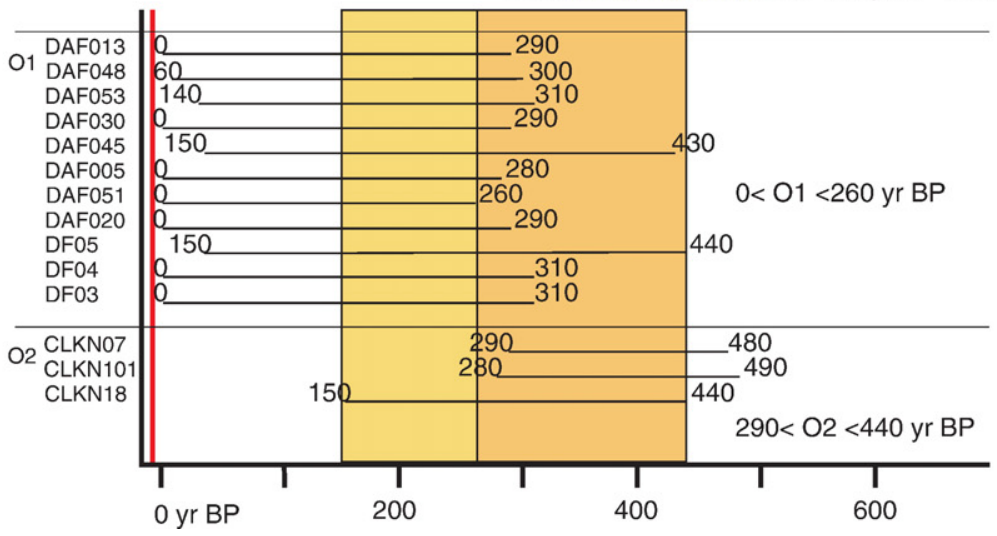


rich soil of unit $\mathrm{O} 3$ that yielded a ${ }^{14} \mathrm{C}$ age of $720-920 \mathrm{cal}$ yr BP (FHS019; Fig. 6a). Most of the gravel beds (units Gc7-Gc1) are well stratified with lenticular sand beds, and appear to have derived from a tributary stream that is located to the north of the site, where Pleistocene conglomerate strata are exposed (Figs. 1a and 2)b. Trench FH2 clearly shows that units Gc6, O2, Gc5, and Gc4 were unconformably onlapped unit $\mathrm{O} 3$ (Fig. 6b). It appears that these washout gravels were deposited on the fault scarp.

The trenches exposed a sequence of alluvial and colluvial deposits that were displaced by three thrust faults ( Fb1, Fb2, and Fb3). By analyzing what we observed in the two trenches, we were able to define three events along these faults. The most recent event (Eb1), which occurred along fault $\mathrm{Fb} 1$, was responsible for the displacement of the top sequence of unit $\mathrm{Gc1}$ and its coverage by the mold of unit $\mathrm{M}$. Fault $\mathrm{Fb} 1$ has been ascribed to the 1951 earthquake, which is known to have created a 1.2-1.5-m vertical displacement in this area (Hsu, 1962). The excavation shows the fault plane to $\mathrm{N} 55^{\circ} \mathrm{E} / 35^{\circ} \mathrm{E}$. The average vertical displacement in the two trenches is about $1.2 \mathrm{~m}$, as defined by the offset units $\mathrm{Gc} 1$ and $\mathrm{O} 1$ in trench FH-1 (Fig. 6a). The displacement appears to coincide well with that of the 1951 earthquake.

The Eb2 event was responsible for the displacement of unit $\mathrm{Gc} 3$ across fault $\mathrm{Fb}$, which is covered by unit $\mathrm{Gc} 2$. The ${ }^{14} \mathrm{C}$ age of unit Gc3 of 300-500 cal yr BP (FHS018) represents the lower chronological limit and the dates of 150-300 cal yr BP (FHS062, 076) for unit Gc2 represent the upper chronological limit for the Eb2 event (Fig. 6a). These dates therefore suggest that the Eb2 event occurred between $150 \mathrm{cal} \mathrm{yr}$ BP and 300-500 cal yr BP (Fig. 5b). The fault plane has the orientations $\mathrm{N} 58^{\circ} \mathrm{E} / 50^{\circ} \mathrm{E}$ with the average vertical displacement of $1.06 \mathrm{~m}$ being defined by the offset of units Gc4 and O2. Because the fault scarp that was created by the Eb2 event has been eroded by unit $\mathrm{Gc} 2$, we cannot estimate the displacement at the fault tip (Fig. 6b).

The Eb3 event was responsible for the displacement of unit $\mathrm{Gc} 5$ across fault $\mathrm{Fb} 3$, which is covered by unit Gc4. The intersection age of 550-640 cal yr BP (FHS030, 059, 065, 066, 079) of unit Gc5 represents the lower chronological limit and the dates of 500-550 cal yr BP (FHS131) for unit Gc4 the upper chronological limit for the Eb3 event (Fig. 6b). Therefore, the Eb3 event is likely to have occurred within the 500-640 cal yr BP (Fig. 5b).
The fault plane has the orientations $\mathrm{N} 47^{\circ} \mathrm{E} / 29^{\circ} \mathrm{E}$. The vertical displacement as defined by the offset units $\mathrm{O} 3$ in trench FH-1 is about $0.7 \mathrm{~m}$ (Fig. 6a).

\subsection{Dafu site}

The Dafu site is located about $2 \mathrm{~km}$ north of the Fushin site across the western strand. The fault at the frontal western hills was responsible for the displacement of Pleistocene conglomerate and Holocene uncemented deposits along the fault scarp (Figs. 1a and 2)c. A surface rupture also occurred here during the 1951 earthquake, although it is not documented on previous maps. We excavated three trenches of about $20 \mathrm{~m}$ long, $6 \mathrm{~m}$ deep and $8 \mathrm{~m}$ wide (DF-1, DF-2, DF-3) across the fault scarp. The excavated profiles show intense disturbance by folding on the hanging wall, with three folds that are related to three reverse faults $(\mathrm{Fc} 1, \mathrm{Fc} 2$, and $\mathrm{Fc} 3$ ). The exposed sediment succession is predominately composed of alluvial and colluvial deposits and two organicrich silty layers (O2 and $\mathrm{O} 1)$ (Fig. 7a, b, and c). The lower units G3 and G2 show stratified gravels with lenticular sand layers of alluvial deposits. Unit G1 consists of matrix-supported gravels that derive from debris-flow deposits, which can be interpreted as colluvial deposits on the fault scarp.

Paleoseismological analysis identified three reverse faults, which infers three displacement events. The Ec1 event along the fault $\mathrm{Fcl}$ was responsible for the displacement of the top sequence of unit $\mathrm{Gl}$, which is capped by unit $\mathrm{M}$. The displacement of fault $\mathrm{Fc} 1$ is thus assumed to have been caused by the 1951 earthquake. The fault plane has the orientations $\mathrm{N} 50^{\circ} \mathrm{E} / 26-30^{\circ} \mathrm{E}$ (Fig. 7a, b, and c). The vertical displacement of fault $\mathrm{Fc} 1$ in the southern wall of trench DF-3 is $2.9 \mathrm{~m}$ as defined by the offset of unit G1, whereas unit O1 displays a vertical displacement of only $0.7 \mathrm{~m}$ across the same fault (Fig. 7c). These observations indicate that fault Fc1 has been subject to at least two events, which we refer to as the Ec1 event (the 1951 earthquake) and the Ec3 event (older). The restoration of the offset of the 1951 earthquake still gives a vertical displacement for fault $\mathrm{Fcl}$ of $2.57 \mathrm{~m}$ and units $\mathrm{G} 2$ and $\mathrm{G} 3$ retain the warping, which intimates that the Ec 3 event occurred after the deposition of unit G2. In addition, the fluvial deposits of unit G2 are preserved on the fault $\mathrm{Fc1}$ hanging wall, which also

Fig. 5. Chronological constraints of the inferred paleoearthquake events and the deposition of stratigraphic units. The red line indicates the Taitung earthquake in $1951 \mathrm{AD}$. The occurrence time estimate corresponds to the color area which is correlated to a paleoearthquake event. (5a) In the Anding Bridge site two events are identified occurring $1951 \mathrm{AD}$ and $140<\mathrm{Ea} 2<330-500 \mathrm{yr} \mathrm{BP}$. (5b) In the Fushin site three events are identified occurring $1951 \mathrm{AD}, 150<\mathrm{Eb} 2<300-500 \mathrm{yr} \mathrm{BP}$, and $500<\mathrm{Eb} 3<550-640 \mathrm{yr} \mathrm{BP}$. (5c) In the Dafu site three events are identified occurring $1951 \mathrm{AD}$, $\mathrm{Ec} 2<260 \mathrm{yr} \mathrm{BP}$, and $150<\mathrm{Ec} 3<290-440 \mathrm{yr} \mathrm{BP}$. 
(a) Southern wall

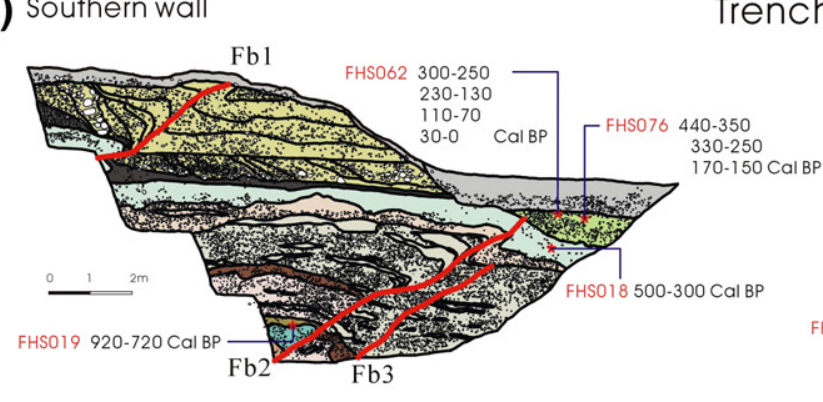

(b)

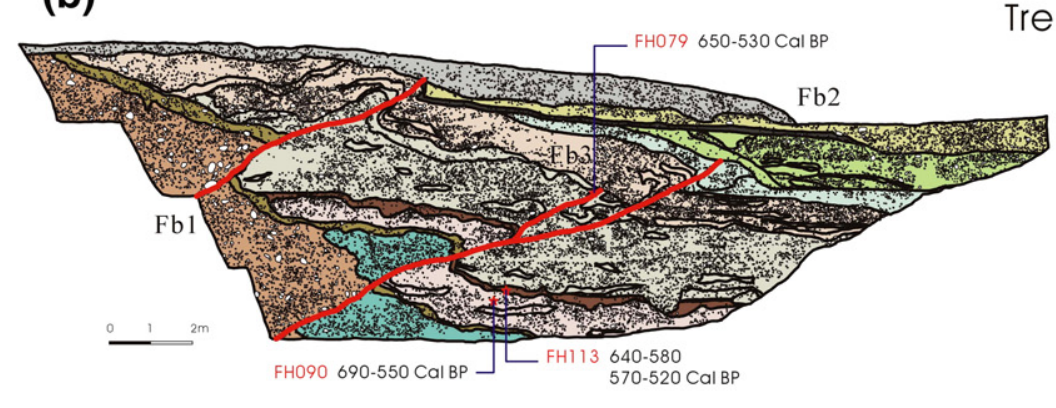

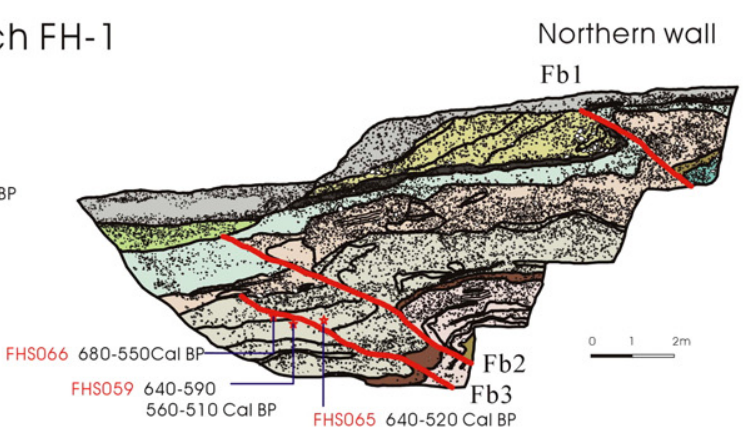

Trench FH-2
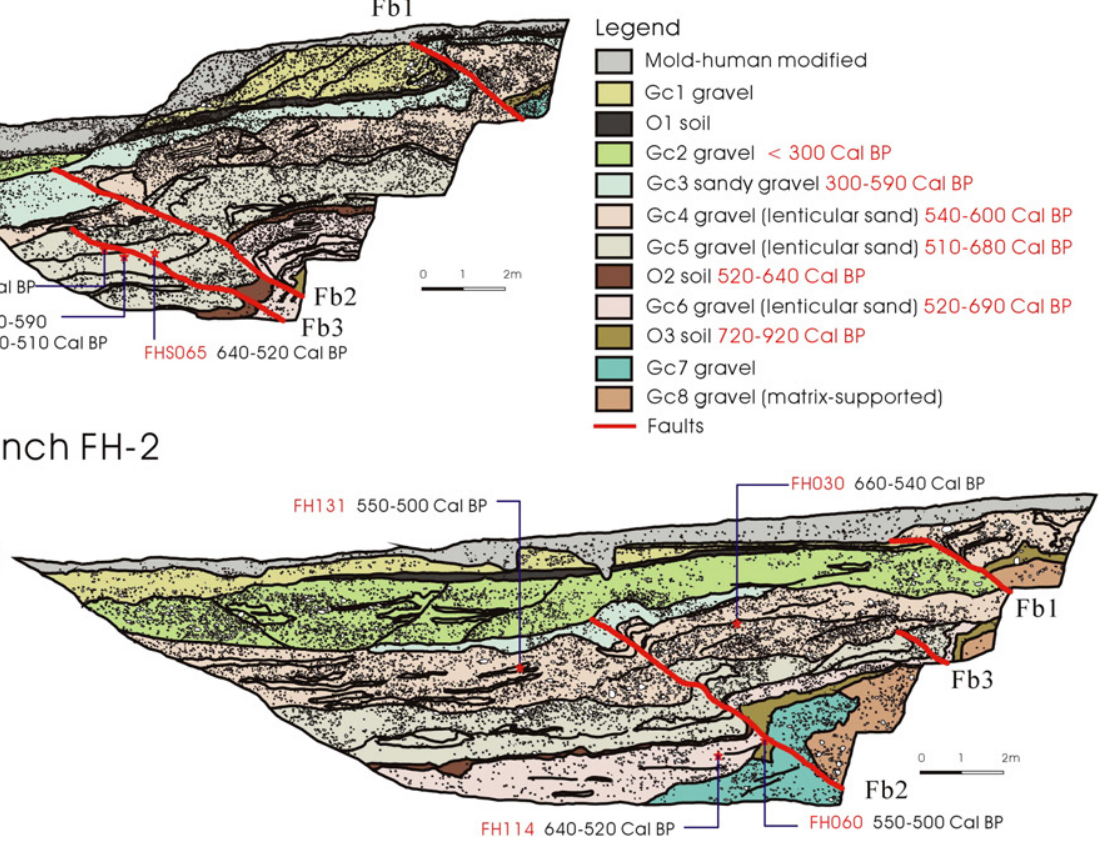

Fig. 6. Trench logs and dated stratigraphy of trench FH-1 (6a) and FH-2 (6b). Red lines mark the faults which show three reverse faults of Fb1, Fb2 and Fb3 in the two trenches. Twelve units of gravel and soil deposits reflect fluctuations of storm deposits. 
(a) Southern wall

\section{Northern wall}

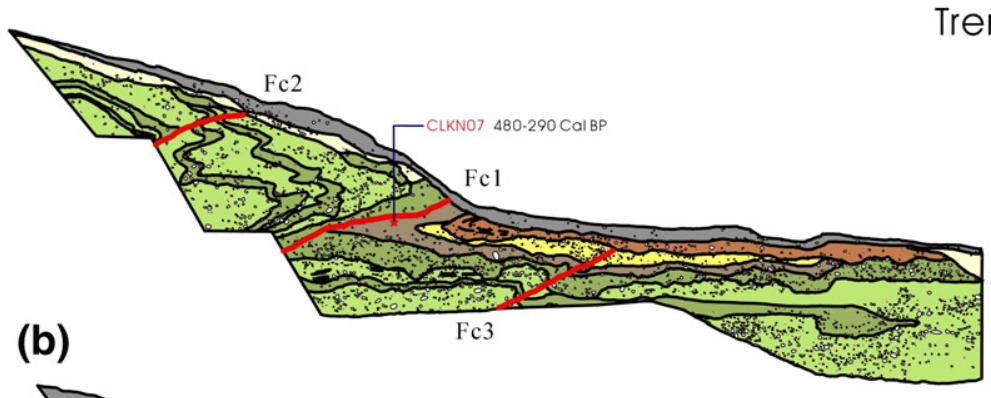

Trench DF-1

(b)

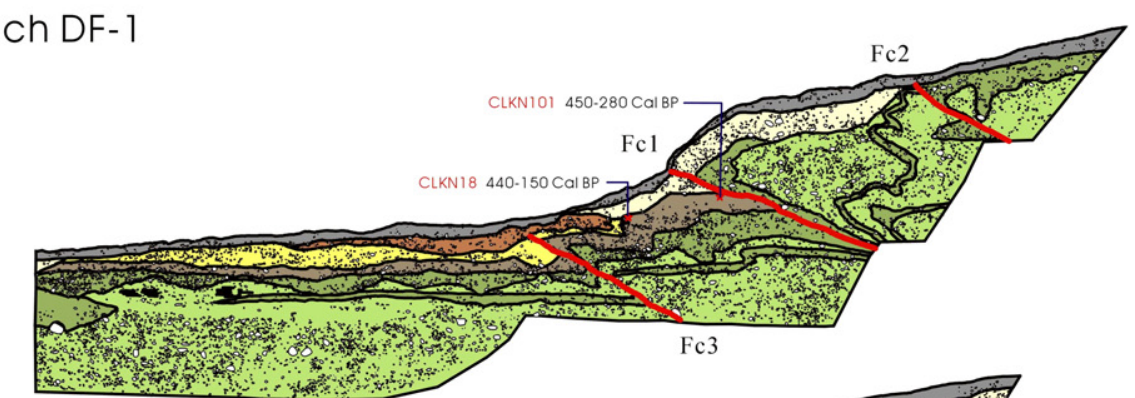

(c)

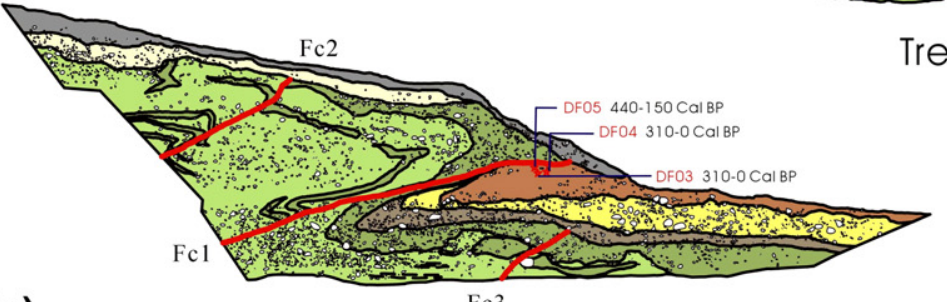

$\mathrm{Fc} 3$
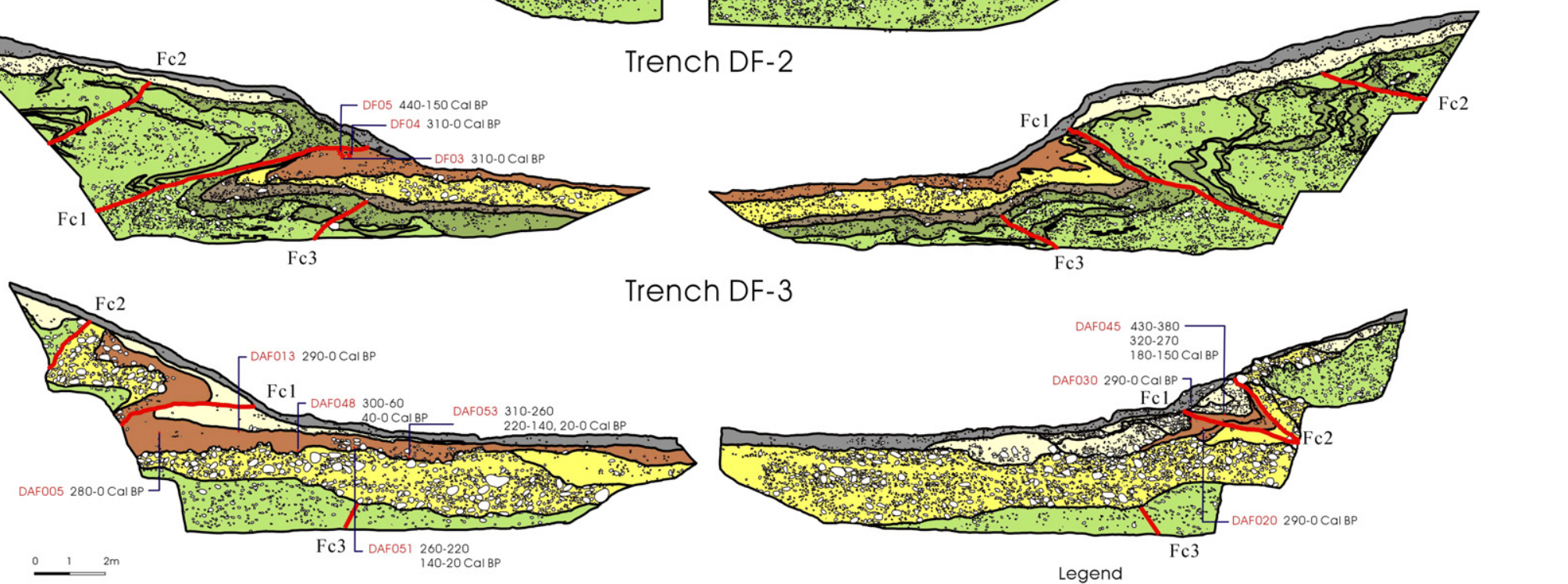

$\square$ Mold-human modified < 50 BP yr

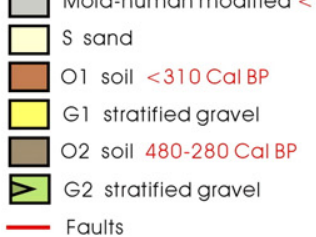

Fig. 7. Trench logs and dated stratigraphy of trench DF-1 (7a), DF-2 (7b) and DF-3 (7c). Red lines mark the faults which show three reverse faults of Fc1, Fc2 and Fc3 in the three trenches. In trench DF-3, the unit O1 was disturbed by fault Fc2 (7c), and the fault tip was covered by the undeformed unit G1 in trench DF-2. 
suggests that unit $\mathrm{G} 2$ was deposited before the $\mathrm{Ec} 3$ event. Our interpretation is that fault $\mathrm{Fc} 1$ represents the slip that resulted from two events; $1.0 \mathrm{~m}$ in 1951 and $2.57 \mathrm{~m}$ from an older event (Ec3).

Units $\mathrm{O} 1, \mathrm{G} 2$, and G3 in trench DF-3 appear to have been displaced by fault Fc2 (Fig. 7c), and the fault tip is covered by the undeformed unit $\mathrm{G} 1$ in the trenches DF-1 and DF-2 (Fig. 7a and b). Thus, the Ec2 event must have occurred after the deposition of unit $\mathrm{O} 1$ and before the deposition of unit G1. Ten detrital charcoal samples that were collected from unit $\mathrm{O} 1$ yielded the age of 150 260 cal yr BP (DAF013, 020, 030, 045, 048, 051, 053, DF03, 04, 05), and thus the Ec2 event must have occurred after $260 \mathrm{cal} \mathrm{yr} \mathrm{BP} \mathrm{(Fig.} \mathrm{5c).} \mathrm{The} \mathrm{fault} \mathrm{plane} \mathrm{has}$ the orientations $\mathrm{N} 54^{\circ} \mathrm{E} / 20-25^{\circ} \mathrm{E}$. The average vertical displacement of unit G3 across the fault Fc2 is $1.22 \mathrm{~m}$.

The Ec4 event was responsible for the displacement of units $\mathrm{G} 2$, O2, and $\mathrm{G} 3$ along fault $\mathrm{Fc} 3$, which is also covered by the undeformed unit $\mathrm{O} 1$. The fault plane has the orientations $\mathrm{N} 68^{\circ} \mathrm{E} / 30^{\circ} \mathrm{E}$ (Fig. $7 \mathrm{a}, \mathrm{b}$, and c). The average vertical displacement of unit $\mathrm{O} 2$ across fault $\mathrm{Fc} 3$ is $0.65 \mathrm{~m}$. The lack of dates for unit $\mathrm{G} 2$ prevents us from defining the upper chronological limit, but using the dates of unit $\mathrm{O} 2$ we obtained the intersection age of 290-440 cal yr BP (CLKN07, 18, 101), which suggests that the Ec4 event occurred between 150-260 cal yr BP and 290-440 cal yr BP, and probably after 290-440 cal yr BP (Fig. 5c). The stratigraphic relationships show the Ec3 and Ec4 displacements to have occurred after the deposition of unit G2, but there is no way to distinguish between the two events. We can infer that the two deformations probably occurred during the same episode of faulting, and can determine that the amount of vertical displacement that occurred as a result of the Ec3 event was $3.4 \mathrm{~m}$. As the correlative deposits occur across all three faults at the Dafu site, it is evident that at least three coseismic displacement events occurred after the period 290-440 cal yr BP (Fig. 5c).

\section{Discussion}

\subsection{Faulting events and recurrence intervals}

We carried out excavations at three sites across two branched faults along the northern part of the Juisui fault. The Anding Bridge and Fushin sites are located on the eastern strand, and provide evidence for the occurrence of three coseismic displaced events. Two of these events (Ea1-Ea2 and Eb1-Eb2) occurred after 300 cal yr BP (Fig. 8). The Eb3 event has been identified as occurring at the Fushin site between 500 and $640 \mathrm{cal} \mathrm{yr} \mathrm{BP,} \mathrm{but} \mathrm{is}$ not recognized as having affected the Anding Bridge site (Fig. 8). The Dafu site, which is located on the western strand, also shows evidence of three coseismic displaced events (Ec1, Ec2, and Ec3), all of which occurred after 290-440 cal yr BP (Fig. 8). All of the trenches show evidence that the most recent displacement event (Ea1, Eb1, and Ec1) was the 1951 earthquake. The other events (Ea2, Ec2, and Ec3) occurred after the limit for conducting ${ }^{14} \mathrm{C}$ dating $(<300 \mathrm{cal}$ yr BP), and thus the exact date of their occurrence could not be determined. The age constraints indicate an event (Ec2 or Ec3) to be missing at the Dafu site, although this could not be further verified due to a lack of stratigraphic records for the eastern strand, but it is likely that the missing event did not occur along the eastern strand. The correlation of the two branched faults allows us to identify four paleoearthquake events in $1951 \mathrm{AD}, \mathrm{P} 2$ event $<260 \mathrm{cal}$

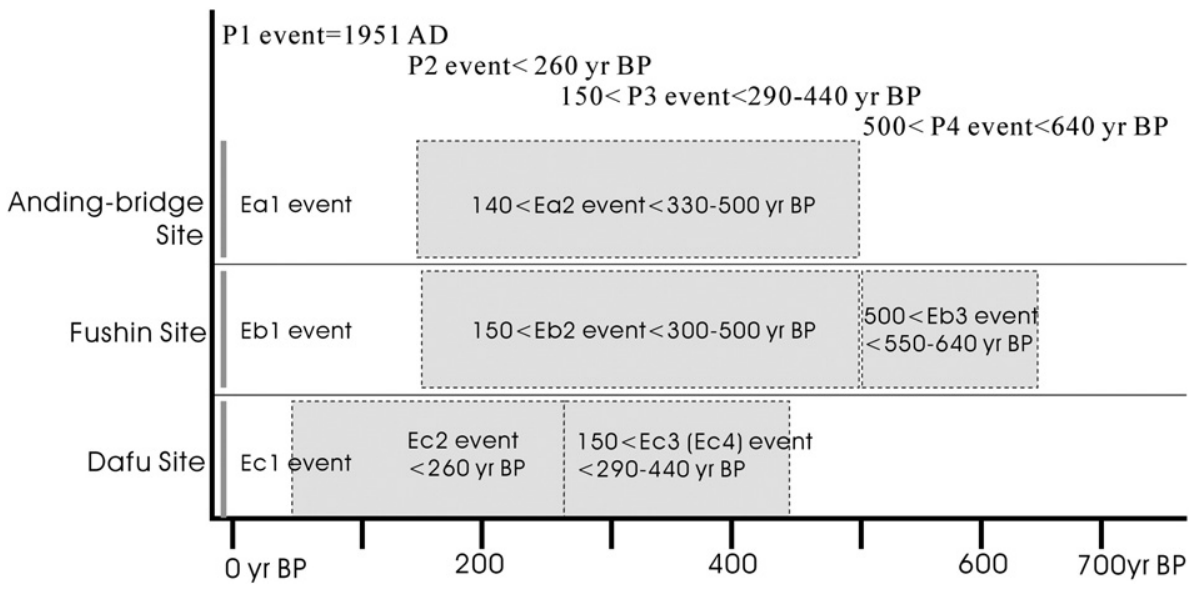

Fig. 8. The seismological history of the Juisui fault is combined with three trench studies. The gray line indicates the Taitung earthquake in $1951 \mathrm{AD}$ The gray boxes are the age ranges of the paleoearthquake events at individual trench sites. 
yr BP, $150<$ P3 event $<290-440$ cal yr BP, and $500<$ P4 event $<640$ cal yr BP (Fig. 8). In summary, there is good quality evidence from the three sites of the occurrence of four large events during the past $700 \mathrm{yr}$. The measured average recurrence interval for the 1951 earthquake through to the $\mathrm{P} 3$ event divided by three intervals permits us to conclude that the average recurrence interval is relatively short at $170-210 \mathrm{yr}$.

\subsection{Slip rates}

Although we found two parallel rupture strands $900 \mathrm{~m}$ apart at the Juisui site (Fig. 9), we assumed that these two fault ramps merge downward of the dip into a single structure at a shallow depth, which would be likely to rupture together during large earthquakes such as that of 1951 earthquake. However, the calculated displacement values should include the displacement of the two strands, but we calculated the displacement that resulted from the
P2 and P3 events using only one of the strands. Thus, the data that we obtained for the vertical displacements from the trench analysis can only provide information on the minimum displacement and slip rates. The average vertical displacement along the eastern strand as a result of earthquake events is $0.98 \mathrm{~m}$ (Ea1, Eb1), $1.4 \mathrm{~m}$ (Ea2, Eb2), and $0.7 \mathrm{~m}$ (Eb3) (Fig. 5a and b), and the average vertical displacement of the western strand is $1.0 \mathrm{~m}(\mathrm{Ec} 1), 1.22 \mathrm{~m}$ (Ec2), and $3.4 \mathrm{~m} \mathrm{(Ec3)} \mathrm{(Fig.} \mathrm{5c).} \mathrm{The} \mathrm{vertical} \mathrm{displace-}$ ments as a result of the 1951 earthquake cross the two strands that amount to $1.98 \mathrm{~m}$. Although we obtained the age of these events through ${ }^{14} \mathrm{C}$ dating, we are still unable to correlate the $\mathrm{Ea} 2(\mathrm{~Eb} 2)$ event with the $\mathrm{Ec} 2$ or $\mathrm{Ec} 3$ events, because the dates for these events are all limited to the period after 290-440 cal yr BP. If the fault experienced a characteristic amount of slippage during past large earthquakes, then we would expect the Ea2 and Ec2 events to have caused the same displacement as the P2 event, and thus the 2.62-m vertical displacement is more
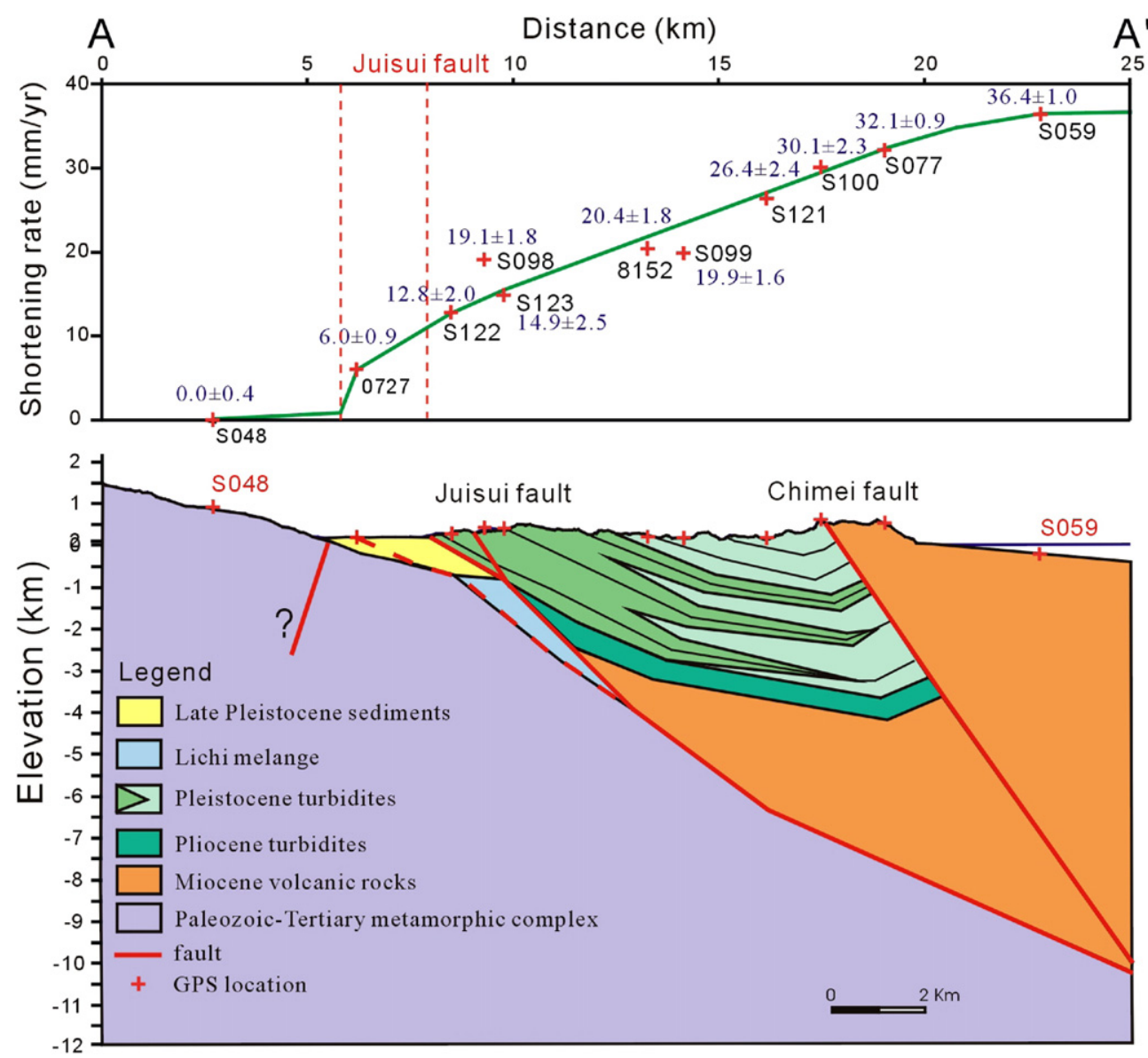

Fig. 9. Geologic profile in the Juisui area across the Juisui fault. The horizontal velocities of GPS data (Yu and Kuo, 2001) projected onto the profile where the location is shown in Fig. 1b. It reveals that the horizontal velocities on the hanging wall gradually decrease westward from $36.4 \pm 1.0$ to $12.8 \pm 2.0 \mathrm{~mm} / \mathrm{yr}$. 
likely to have been caused by the 1951 earthquake (P1 event). In addition, the P3 event (Ec3) induced large surface rupturing and a vertical displacement of $3.4 \mathrm{~m}$, which is much larger than that of the other events. Therefore, we propose the P3 event to be an independent event at the three sites that only occurred along the western strand. The P4 event (Eb3), which appears to have caused a smaller vertical displacement of $0.7 \mathrm{~m}$, was much weaker than the P1, P2, and P3 events, and thus we believe that the oldest event has yet to be discovered at the Dafu site. An alternative interpretation is that the site experienced a relatively small earthquake that only occurred along the eastern strand.

Using the amount of vertical displacements that is associated with each of the earthquake events at the three sites, we estimated the average uplift rate during the four most recent large earthquake events. These four events are associated with a vertical displacement of $1.98,2.62$, 3.4 and $>0.7 \mathrm{~m}$, respectively. Dividing the amount of vertical displacement by the age yields an average uplift rate of $12.5-16.0 \mathrm{~mm} / \mathrm{yr}$ after the $\mathrm{P} 4$ event. This rate is less than the incision rate of about $15.1-19.3 \mathrm{~mm} / \mathrm{yr}$ for the strath terraces on the hanging wall of the Juisui fault (Shyu et al., 2006). A possible reason for this result is that the calculated uplift rate does not take into consideration the deformation of another branched fault at the footwall of the two strands. GPS observations of the footwall suggest surface horizontal shortening at a rate of $12.8 \pm 2.0 \mathrm{~mm} / \mathrm{yr}$ at an azimuth of $294^{\circ}$ relative to the Central Range (Fig. 9) (Yu and Kuo, 2001). In addition, the geomorphic expression reveals the alluvial fans on the eastern portion of the Longitudinal Valley to have steeper downstream slopes. It appears that most of deformation that has occurred in the central part of the Longitudinal Valley is due to a branched fault at the footwall of the Juisui fault. Although there is a cluster of small earthquake hypocenters, it is difficult to visualize and map the fault plane in this area (Kuochen et al., 2004). We speculate that the Longitudinal Valley fault probably has a wide deformation zone that consists of several parallel reverse faults (Fig. 9).

The uplift rate of $12.5-16.0 \mathrm{~mm} / \mathrm{yr}$ is based on the cumulative vertical displacements across the two fault strands. Assuming a fault dip of $30^{\circ}$, thus we can be converted to calculate a horizontal shortening rate of 21.6-27.7 $\mathrm{mm} / \mathrm{yr}$. GPS data have given the average shortening of arc-continent collision at an azimuth of $294^{\circ}$ to be $62 \pm 0.6 \mathrm{~mm} / \mathrm{yr}$ (Yu and Kuo, 2001). It would therefore appear that about $35-45 \%$ of the total shortening that has been induced by the westward movement of the Coastal Range has occurred along the Juisui fault. Most of the plate shortening can obviously be attributed to the boundary fault, but the rapid slip rate reflects a short recurrence interval.

\subsection{Fault behavior}

The study area corresponds to a major tectonic discontinuity along the Longitudinal Valley fault that accommodates about $50 \%$ of the convergence between the Eurasian continental plate and the Philippine Sea plate. Yu and Kuo (2001) evaluated GPS geodetic data from the Central Range and the Coastal Range and found the shortening rate to be $23-36 \mathrm{~mm} / \mathrm{yr}$ at an azimuth of 284-294 in the middle and southern portions of the Longitudinal Valley. The following mention that we will compare these GPS data with the surface deformation pattern across the Juisui and Chihshang faults to characterize the individual fault behavior.

The Chihshang fault displays rapid creeping that follows a steeper gradient at horizontal velocities across the fault and yields a shortening rate of $26.4 \pm 1.7 \mathrm{~mm} / \mathrm{yr}$ at an azimuth of $285^{\circ}$ perpendicular to the fault trace (Figs. $1 \mathrm{~b}$ and 10). The horizontal velocities of the hanging wall show a uniform constant shortening rate of $26.4 \pm 1.7-28.0 \pm 1.5 \mathrm{~mm} / \mathrm{yr}$, which actually means that there is no surface shortening over a $18-\mathrm{km}$ wide region on the Coastal Range. Apparently, the Chihshang fault accommodates most of the shortening into constant deformation. The uniform deformation pattern implies that the fault is undergoing free slip at both the shallow creep portion and the deeper locked portion of the fault (Angelier et al., 1997, 2000; Lee et al., 2001). Our paleoseismic studies of this fault have defined at least four paleoearthquake events in the past $1000 \mathrm{yr}$. The individual deformation produced surprisingly small vertical displacements from 15 to $65 \mathrm{~cm}$ (in preparation). The $2003 \mathrm{Mw}$ 6.8 Chengkung earthquake also created small vertical displacements of about $20 \mathrm{~cm}$ near the fault tip during the coseismic and post-seismic periods (Lee et al., 2006). Based on GPS data and paleoseismic studies, we speculate that the Chihshang fault usually experiences a small degree of displacement from a large earthquake with a relatively deep epicenter, and that most of the stress at the shallow surface level is released during interseismic periods, such as the $2003 \mathrm{Mw} 6.8$ Chengkung earthquake and the 1951 Ms 6.8 Taitung earthquake (first shock).

With the Central Range as the fixed reference frame, the horizontal velocities were measured in a profile that was perpendicular to the Juisui fault traces at an azimuth of $294^{\circ}$ (Fig. 1b). The measurements from the coast to the Juisui fault tip reveal the horizontal velocities to reduce $23.6 \pm 3.0 \mathrm{~mm} / \mathrm{yr}$ which decrease gradually westward 


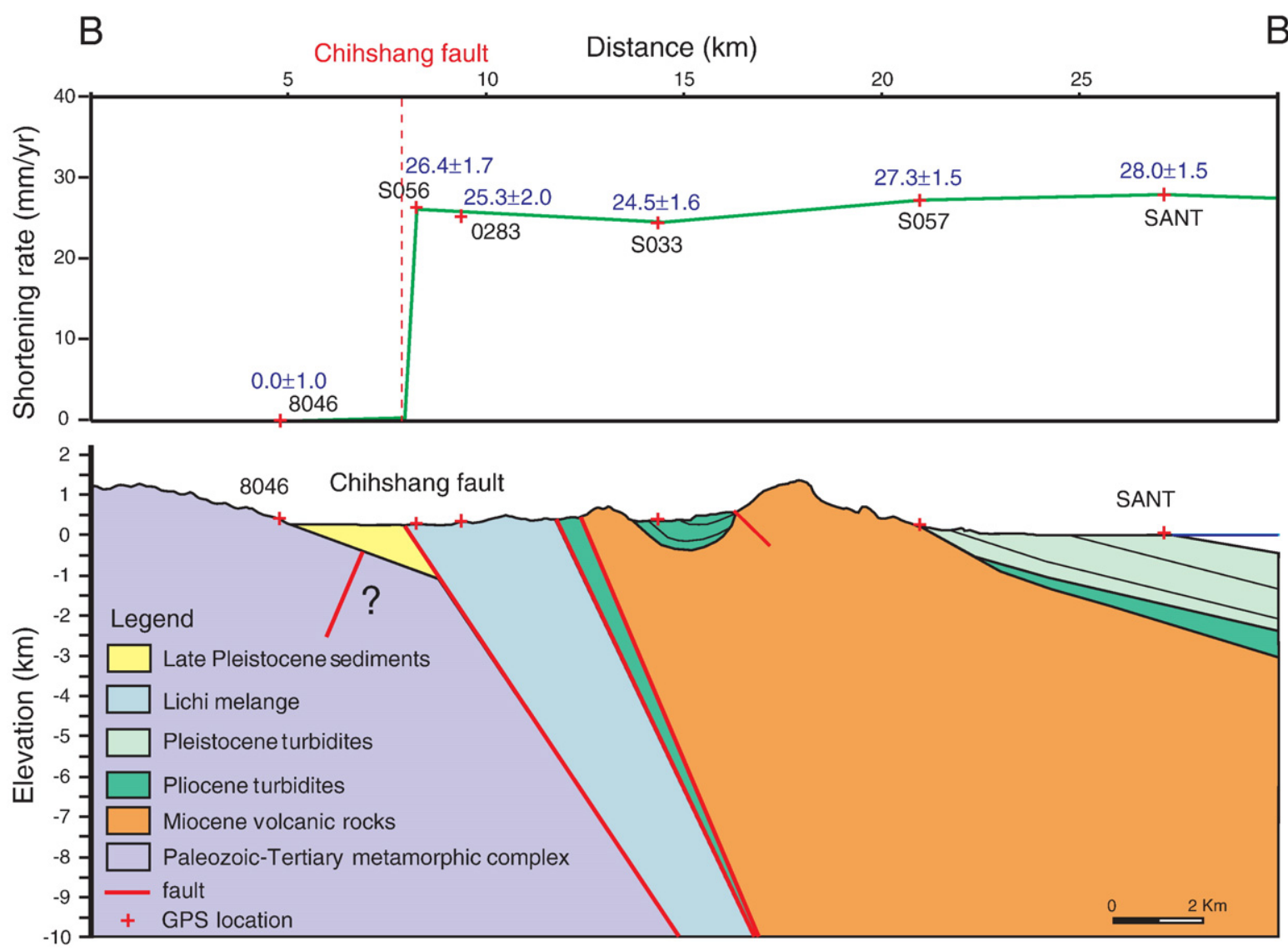

Fig. 10. Geologic profile in the Chihshang area across the Chihshang fault. The horizontal velocities of GPS data (Yu and Kuo, 2001) projected onto the profile where the location is shown in Fig. 1b. It reveals that the horizontal velocities on the hanging wall are rather uniform at a constant rate of about $26.4 \pm 1.7-28.0 \pm 1.5 \mathrm{~mm} / \mathrm{yr}$.

from $36.4 \pm 1.0$ to $12.8 \pm 2.0 \mathrm{~mm} / \mathrm{yr}$. On the footwall of the Juisui fault, the velocities have reduced $12.8 \pm 2.0 \mathrm{~mm} / \mathrm{yr}$ across another branched fault (Fig. 9). The surface horizontal deformation is therefore widely distributed across the Coastal Range over a $20-\mathrm{km}$ wide region and is responsible for a shortening rate of about $36.4 \pm 2.0 \mathrm{~mm} / \mathrm{yr}$. Hsu et al. (2003) use an elastic half-space dislocation model to predict the long-term shortening rate (interseismic slip rate) of $35 \mathrm{~mm} / \mathrm{y}$ across the middle segment of the Longitudinal Valley fault zone. The estimated interseismic slip rate appears to be consistent with the surface deformation field for GPS measured slip deficit across the Longitudinal Valley fault zone. Although we are unable to only assess interseismic slip rate to the Juisui fault, but we think the estimated slip rate roughly equal to GPS measured slip deficit.

The GPS data on the hanging wall of the Juisui fault show a gradual decrease of horizontal velocity with an interseismic slip deficit of $23.6 \pm 3.0 \mathrm{~mm} / \mathrm{yr}$ near the fault tip. The trench analysis reveals the dip in the fault to be around $27^{\circ}$ to $33^{\circ}$, with an average of $30^{\circ}$. The geometry that is presented here gives the coseismic horizontal shortening rate of $21.6-27.7 \mathrm{~mm} / \mathrm{yr}$. Compared with the short-timescale, however, the coseismic horizontal rate is consistent with the interseismic slip deficit at the fault tip according to the GPS data. It appears that the current strain accumulation and late Holocene strain release are the same. The decreasing interseismic deformation pattern demonstrates that the Juisui fault is probably locked at a shallow depth during interseismic periods.

\section{Conclusions}

Because the plate boundary fault of the Longitudinal Valley fault accommodated about $50 \%$ of the total horizontal shortening of the Taiwan orogenic belt, we infer that faulting due to large earthquakes is likely to recur at relatively short intervals. This inference is supported by the fact that our paleoseismological study obtains at least four surface faulting events during the 
past $700 \mathrm{yr}$. Thus, the average recurrence interval between large earthquakes is estimated to be a relatively short time of $170-210 \mathrm{yr}$. This implies that it is not very likely that a large earthquake that is comparable to that which occurred in $1951 \mathrm{AD}$ will happen in the next century, but we cannot completely rule out a moderate earthquake (M 6-7) on the scale of the 1972 Ms 6.8 earthquake, which produced no striking surface rupture.

To further understand the behavior of the fault, we analyzed the deformation across the middle and southern segments of the Longitudinal Valley fault using GPS and paleoseismic data, and found that the deformation behavior of the middle segment (the Juisui fault) is clearly different from the southern segment (the Chihshang fault). The Juisui fault indicates that it is probably locked at a shallow depth, and the great earthquake often produced a visible surficial rupture occurring more than 0.65-m-high vertical displacements. The Chihshang fault reveals a creeping fault that is free slip at the shallow portion of the fault, and the surficial rupture that only produced a small amount of some tens centimeter high when the great earthquake. The seismic activity also characters the current fault behavior that the middle segment has been aseismicity of $M_{\mathrm{L}}>3$, and the southern segment displayed a higher seismicity of $M_{\mathrm{L}} 5-6.8$ during the past several decenniums.

\section{Acknowledgements}

This research was supported by the Taiwan Earthquake Research Center (TEC) funded through National Science Council with grant NSC 95-2119-M002-042 and Central Geological Survey, Taiwan grant 5226902000-02-95-01.

\section{References}

Angelier, J., Chu, H.T., Lee, J.C., 1997. Shear concentration in a collision zone: kinematics of the Chihshang Fault as revealed by outcrop-scale quantification of active faulting, Longitudinal Valley, eastern Taiwan. Tectonophysics 274, 117-143.

Angelier, J., Chu, H.T., Lee, J.C., Hu, J.C., 2000. Active faulting and earthquake hazard: the case study of the Chihshang Fault, Taiwan. J. Geodynamics 29, 151-185.

Barrier, E., Angelier, J., 1986. Active collision in eastern Taiwan: the Coastal Range. Tectonophysics $125,39-72$.

Bonilla, M.G., 1977. Summary of Quaternary faulting and elevation changes in Taiwan. Mem. Geol. Soc. China 2, 43-56.

Chen, W.S., Wang, Y., 1988. The Plio-Pleistocene basin development in the Coastal Range of Taiwan. ACTA Geol. Taiwanica 26, 37-56.

Chen, W.S., 1997a. Lithofacies analyses of the arc-related sequence in Coastal Range, eastern Taiwan. J. Geol. Soc. China 40, 313-338.

Chen, W.S., 1997b. Mesoscopic structures developed in the Lichi mélange during arc-continent collision in Taiwan region. J. Geol. Soc. China 40, 415-434.
Chen, W.S. Tectonic evolution of sedimentary basins in Coastal Range, Taiwan (in Chinese), Ph.D. thesis, Natl. Taiwan Univ. Taipei (1988).

Chen, C.Y., 1974. Verification of the north-northeastward movement of the Coastal Range, eastern Taiwan, by re-triangulation (in Chinese). Bull. Geol. Surv. Taiwan 24, 119-123.

Chen, W.S., Huang, M.T., Liu, T.K., 1991. Neotectonic significance of the Chimei fault in the Coastal Range, Eastern Taiwan. Proc. Geol. Soc. China 34, 43-56.

Chen, W.S., Lee, K.J., Lee, L.S., Daniel, J.P., Prentice, C., Chen, Y.G., Chang, H.C., Lee, Y.H., 2004. Paleoseismology of the Chelungpu fault during the past 1900 years. Quat. Int. 115-116, 167-176.

Chen, W.S., Yang, C.C., Yen, Y.C., Lee, L.S., Lee, K.J., Yang, H.C., Chang, H.C., Ota, Y., Lin, C.W., Lin, W.H., Shih, T.S., Lu, S.T., 2007. Late Holocene paleoseismicity of the southern portion of the Chelungpu Fault, Central Taiwan: evidence from the Chushan excavation site. Bull. Seism. Soc. Am. 97, 1B. doi:10.1785/0120050161.

Chen, W.S., Lee, K.J., Lee, L.S., Streig, A.R., Chang, H.C., Lin, C.W. Significant sedimentation of coseismic fault-propagation growthfold in the Chichi earthquake rupture, central Taiwan, J. Asian Earth Sci. (in press).

Cheng, S.N., Yeh, Y.T., Yu, M.S., 1996. The 1951 Taitung earthquake in Taiwan. J. Geol. Soc. China 39, 267-285.

Cheng, W.B., Wang, C., Shyu, C.T., Shin, T.C., 2002. Crustal structure of the convergent plate-boundary zone, eastern Taiwan, assessed by seismic tomography. In: Byne, T.B., Liu, C.S. (Eds.), Geology and Geophysics of an Arc-Continent Collision, Taiwan, Republic of China: Boulder, Colorado. Geol. Soc. Amer. Spec. Paper, vol. 358, pp. 161-175.

Hsu, T.L., 1956. Geology of the Coastal Range, eastern Taiwan. Bull. Geol. Surv. Taiwan 8, 39-64.

Hsu, T.L., 1962. Recent faulting in the Longitudinal Valley Fault of eastern Taiwan. Mem. Geol. Soc. China 1, 95-102.

Hsu, Y.J., Simoes, M., Yu, S.B., Kuo, L.C., Chen, H.Y., 2003. A twodimensional dislocation model for interseismic deformation of the Taiwan mountain belt. Earth Planet. Sci. Lett. 211, 284-287.

Hu, J.C., Cheng, L.W., Chen, H.Y., Wu, Y.M., Lee, J.C., Chen, Y.G., Lin, K.C., Rau, R.J., Kuochen, H., Chen, H.H., Yu, S.B., Angelier, J., 2007. Coseismic deformation revealed by inversion of strong motion and GPS data: the 2003 Chengkung earthquake in eastern Taiwan. Geophys. J. Int. 169, 667-674. doi:10.1111/j.1365246X.2007.03359.x.

Kuochen, H., Wu, Y.M., Chang, C.H., Hu, J.C., Chen, W.S., 2004. Relocation of the eastern Taiwan earthquakes and its tectonic implications. Terr. Atmos. Oceanic Sci. 15, 647-666.

Lee, J.C., Angelier, J., Chu, H.T., Hu, J.C., Jeng, F.S., 2001. Continuous monitoring of an active fault in a plate-suture zone: a creepmeter study of the Chihshang active fault, eastern Taiwan. Tectonophysics 333, 219-240.

Lee, J.C., Angelier, J., Chu, H.T., Hu, J.C., Jeng, F.S., Rau, R.J., 2003. Active fault creep variations at Chihshang, Taiwan, revealed by creep meter monitoring, 1998-2001. J. Geophys. Res. 108 (B11), 2528.

Lee, J.C., Chu, H.T., Angelier, J., Hu, J.C., Chen, H.Y., Yu, S.B., 2006. Quantitative analysis of surface coseismic faulting and postseismic creep accompanying the $2003, \mathrm{Mw}=6.5$, Chengkung earthquake in eastern Taiwan. J. Geophys. Res. 111, B02405. doi:10.1029/ 2005JB003612.

Lin, Y.C. Mesoscopic features in the Lichi mélange shear zone: implications for tectonic significance due to the arc-continent collision (in Chinese). MS. thesis, Natl. Taiwan Univ. Taipei (1993).

Liu, T.K., Chen, Y.G., Chen, W.S., Jiang, S.H., 2000. Rates of cooling and denudation of the Early Penglai Orogeny, Taiwan, as assessed by fission-track constraints. Tectonophysics $320,69-82$. 
Liu, T.K., Hsieh, S.R., Chen, Y.G., Chen, W.S., 2001. Thermo-kinematic evolution of the obliquely collisional Taiwan mountain belt as revealed by fission track ages for detrital zircons. Earth Planet. Sci. Lett. 186, 45-56.

Shin, T.C., Chang, C.S., 1992. Earthquake in 1992. Meteorl Bull. 38, $218-232$.

Shyu, J.B.H., Sieh, K.E., Avouac, J.P., Chen, W.S., Chen, Y.G., 2006. Millennial slip rate of the Longitudinal Valley fault from river terraces: Implications for convergence across the active suture of eastern Taiwan. J. Geophys. Res. 111, B08403. doi:10.1029/ 2005JB003971.

Simoes, M., Avouac, J.P., 2006. Investigating the kinematics of mountain building in Taiwan from the spatiotemporal evolution of the foreland basin and western foothills. J. Geophys. Res. 111, B10401. doi:10.1029/2005JB004209.

Simoes, M., Avouac, J.P., Chen, Y.G., Singhvi, A.K., Wang, C.Y., Jaiswal, M., Chan, Y.C., Bernard, S., 2007. Kinematic analysis of the Pakuashan fault tip fold, west central Taiwan: shortening rate and age of folding inception. J. Geophys. Res. 112, B03S14. doi:10.1029/2005JB004198.

Suppe, J., 1981. Mechanics of mountain building and metamorphism in Taiwan. Mem. Geol. Soc. China 4, 67-89.
Teng, L.S., 1987. Tectonostratigraphic facies and geologic evolution of the Coastal Range, eastern Taiwan. Mem. Geol. Soc. China 8, 229-250.

Wang, Y., Chen, W.S., 1993. Geological map of eastern Coastal Range. 1:100,000. Cent. Geol. Surv. Taiwan.

Wu, Y.M., Chen, Y.G., Shin, T.C., Kuochen, H., Hou, C.S., Hu, J.C., Chang, C.H., Wu, C.F., Teng, T.L., 2006. Coseismic versus interseismic ground deformations, fault rupture inversion and segmentation revealed by $2003 \mathrm{Mw} 6.8$ Chengkung earthquake in eastern Taiwan. Geophys. Res. Lett. 33, L02312.

York, J.E., 1976. Quaternary faulting in eastern Taiwan. Bull. Geol. Surv. Taiwan 25, 63-72.

Yu, S.B., Kuo, L.C., 2001. Present-day crustal motion along the Longitudinal Valley Fault, eastern Taiwan. Tectonophysics 333, 199-217.

Yu, S.B., Lee, C., 1986. Geodetic measurement of horizontal crustal deformation in eastern Taiwan. Tectonophysics 125, 73-85.

Yu, S.B., Liu, C.C., 1989. Fault creep on the central segment of the Longitudinal Valley Fault, eastern Taiwan, Proc. Geol. Soc. China 32, 209-231.

Yu, S.B., Yu, G.K., Kuo, L.C., Lee, C., 1992. Crustal deformation in the southern Longitudinal Valley area, eastern Taiwan. J. Geol. Soc. China 35, 219-230. 